\title{
Genomic DNA restriction site heterogeneity in bovine Pasteurella multocida serogroup $A$ isolates detected with an rRNA probe
}

\author{
S. M. DABO, B. M. DEBEY*, M. MONTELONGO and A. W. CONFER \\ Department of Anatomy, Pathology and Pharmacology, College of Veterinary Medicine, Oklahoma State \\ University, Stillwater, OK 74078 and ${ }^{*}$ College of Veterinary Medicine, Kansas State University, Manhattan, KS \\ 66506, USA
}

\begin{abstract}
A total of 81 Pasteurella multocida isolates from healthy and diseased dairy and beef cattle originating from various geographical locations was examined by rRNA gene restriction site polymorphism analysis (ribotyping), restriction endonuclease analysis (REA), SDS-PAGE analysis of whole-cell (WCP) and outer-membrane (OMP) proteins, and capsule and somatic serotyping. Bacterial strains were isolated from nose, lung and in one case testicle, of Holstein and cross-bred beef cattle. The isolates represented for the most part serogroup A3 (88\%). Ribotyping was performed on DNA digested with Hae II, electrophoresed and then hybridised with ${ }^{32} \mathrm{P}$-labelled 16S-23S rRNA from Escherichia coli. Six ribotypes (R1-R6) and 10 REA types were found among the 81 isolates with similar discrimination index (DI) of $c$. 0.60 . Protein profiles revealed reproducibility and high levels of polymorphisms among lung isolates. Isolates were compared according to their geographical habitat, their isolation from dairy or from beef cattle and from nasal cavities or lungs. No correlation was apparent between geographical locations and ribotypes. Overall, isolates obtained from dairy cattle were predominantly R1, whereas those obtained from beef cattle were equally distributed between $R 1$ and $R 2$. R1 was more representative of lung isolates. For some strains, particularly the single isolate ribotypes, good correlation was achieved between WCP analysis, REA types and ribotypes. For others, REA to some extent and WCP profiles were able to discriminate among isolates within ribotypes. The data suggest that a combination of ribotyping, REA and WCP analysis is useful for investigating the epidemiology of bovine $P$. multocida serogroup $A$.
\end{abstract}

\section{Introduction}

Pasteurella multocida, a pathogenic gram-negative bacterium with coccoid or short rod morphology, has a broad host range including most mammals, birds and man [1]. It contributes substantially to bovine pneumonic pasteurellosis, which causes major economic losses to beef cattle and dairy industries in the USA [2].

P. multocida comprises five capsular serogroups of 16 somatic serotypes [1,3]. In cattle, $P$. multocida serogroups $B$ and $E$ are the pathogens of bacterial haemorrhagic septicaemia, and serogroup A is mainly associated with respiratory disease $[1,4,5]$. P. multo-

Received 2 June 1998; accepted 7 July 1998.

Corresponding author: Dr S. M. Dabo (e-mail: mdvpathe@) okway.okstate.edu). cida $\mathrm{A} 3$ is the second most commonly isolated bacterium from fibrinous pneumonia in beef cattle (with prevalence of 21-34\%) and the major cause of fibrinopurulent pneumonia in dairy calves $(>65 \%)$ [69].

In epidemiology and other fields of applied microbiology, reliable methods for the identification and characterisation of bacterial strains within a particular genus and species are primary requirements. Several methods have been used to differentiate bacterial strains, including those of $P$. multocida [10-19]. Traditional phenotypic methods, such as outer-membrane-protein (OMP) subtyping, whole-cell-protein (WCP) analysis, serotyping and biotyping $[11,14$, $18,20-25]$ are not sensitive enough for strain differentiation. Restriction endonuclease analysis (REA) of whole genomic DNA has been useful in the genetic characterisation of bacterial strains $[11,16$, 
26-28], but its limitations have led to the use of Escherichia coli ribosomal RNA (rRNA) as a broadspectrum probe (ribotyping) for both epidemiological and taxonomic purposes [29-37]. Recently, Townsend et al. [38] used ribotyping and field alternation gel electrophoresis (FAGE) to differentiate P. multocida isolates from haemorrhagic septicaemia. To our knowledge, the discriminatory power and application of molecular techniques have not been investigated in bovine P. multocida serogroup A isolates from the respiratory tract. Furthermore, there are no discriminating data available on such bovine $P$. multocida isolates in relation to animal group, organ or geographical habitat.

In this study, 81 bovine P. multocida isolates from healthy and diseased dairy and beef cattle originating from different geographical locations were characterised by five molecular and traditional typing methods - serotyping, SDS-PAGE of WCP and OMPs, REA of whole genomic DNA and ribotyping.

\section{Materials and methods}

\section{Bacterial strains and growth conditions}

Eighty-one $P$. multocida isolates were examined (Table 1). They were isolated from nose (33), lung (47) and testicle (1) of Holstein (48) and cross-bred beef cattle (33). The isolates were collected from animals in Oklahoma (51), California (28), Kansas (1) and Missouri (1). They were grown on Bacto Brain-Heart Infusion (BHI) Agar (Difco Laboratories, Detroit, MI, USA), at $37^{\circ} \mathrm{C}$ in air with $\mathrm{CO}_{2} 5 \%$ overnight [39]. For broth cultures, overnight seed cultures were used to inoculate BHI broth and grown to a mid-logarithmic phase at $37^{\circ} \mathrm{C}$ with shaking.

\section{Capsule and somatic serotyping}

Serogrouping was performed according to Rimler [19] by hyaluronidase, chondroitinase $\mathrm{AC}$ and heparinase III

Table 1. Origin of the P. multocida isolates

\begin{tabular}{llrrr}
\hline $\begin{array}{l}\text { Group } \\
\text { and site }\end{array}$ & Source & $\begin{array}{c}\text { Number of } \\
\text { isolates }\end{array}$ & State & Total \\
\hline Holstein cattle & & & & 48 \\
Nasal & Random & 1 & Ok & \\
& Farm A & 14 & Ok & 15 \\
Lung & Random & 28 & $\mathrm{Ca}$ & \\
Testicle & Random & 4 & Ok & 32 \\
Beef cattle & Random & 1 & Ok & 1 \\
Nasal & Random & 1 & Ok & 33 \\
& Farm B & 6 & Ok & \\
Lung & Farm C & 11 & Ok & 18 \\
& Random & 13 & Ok & \\
& Random & 1 & $\mathrm{Ks}$ & \\
& Random & 1 & $\mathrm{Mo}$ & 15 \\
\hline
\end{tabular}

sensitivity tests. Serotyping was performed by agar gel precipitation with serotype specific antisera [5].

\section{SDS-PAGE of whole-cell and outer-membrane proteins}

Bacterial envelopes were prepared by sonication [40]. The Sarkosyl insoluble (SI) method, which is based on the differential solubility of cytoplasmic (inner) and outer membranes in n-lauroyl sarcosine, was used as described previously [41]. Twelve $P$. multocida isolates, including a representative of each ribotype, were selected for OMP extraction. Whole-cell lysates were obtained and SDS-PAGE was done as described previously [42]. Protein bands were visualised after staining with Coomassie Brilliant Blue R250 (Fisher Scientific, Fair Lawn, NJ, USA) $0.1 \% \mathrm{w} / \mathrm{v}$ in acetic acid $10 \% \mathrm{v} / \mathrm{v}$, methanol $40 \% \mathrm{v} / \mathrm{v}$ for $1 \mathrm{~h}$ at room temperature with gentle shaking and then de-staining in acetic acid $10 \% \mathrm{v} / \mathrm{v}$, methanol $10 \% \mathrm{v} / \mathrm{v}$.

\section{Genomic DNA preparation, REA and separation of DNA fragments}

Genomic DNA of high mol.wt was prepared with a Qiagen DNA mini prep kit according to the manufacturer's instructions (Qiagen, Santa Clarita, CA, USA). Residual proteins were removed by phenol-chloroform extraction and DNA was precipitated with 2.5 volumes of cold absolute ethanol and $0.3 \mathrm{M}$ ammonium acetate at $-20^{\circ} \mathrm{C}$ overnight. The preparation was centrifuged at $12000 \mathrm{rpm}$ in a microcentrifuge at $4^{\circ} \mathrm{C}$ for $30 \mathrm{~min}$. Pellets were washed with ethanol $70 \% \mathrm{v} / \mathrm{v}$, dried, dissolved in $200 \mu \mathrm{l}$ of TE buffer and stored at $4^{\circ} \mathrm{C}$. DNA concentration was measured spectrophotometrically at $260 \mathrm{~nm}$ [43]. For ribotyping and REA, purified DNA $(3 \mu \mathrm{g})$ was digested overnight at $37^{\circ} \mathrm{C}$ in $20-\mu \mathrm{l}$ volumes containing the restriction endonucleases, according to manufacturer's instructions (Promega Corporation, Madison, WI, USA). Selected restriction endonuclease digests were checked continuously for reproducibility of the method. The digested DNA was electrophoresed at $24 \mathrm{~V}$ (constant voltage) overnight in agarose (Gibco-BRL, Grand Island, NY, USA) 0.7\% $\mathrm{w} / \mathrm{v}$ in TBE buffer $(89 \mathrm{mM}$ Tris base, $89 \mathrm{mM}$ boric acid, $2.4 \mathrm{mM}$ sodium EDTA, pH 8.0) and TAE buffer (40 mM Tris base, 1 mM EDTA, $\mathrm{pH} 8.0$ ), respectively for ribotyping and REA.

\section{Radiolabelling of $r R N A$}

Ribosomal 16S-23S RNA (3 $\mu \mathrm{g})$ from $E$. coli (Boehringer Mannheim, Indianapolis, IN, USA) was alkaline hydrolysed with an equal volume of $100 \mathrm{mM}$ sodium bicarbonate $\left(\mathrm{NaHCO}_{3}\right), \mathrm{pH} 9$, at $95^{\circ} \mathrm{C}$ for $20 \mathrm{~min}$, precipitated with 2.5 volumes of absolute ethanol and $0.3 \mathrm{M} \mathrm{NaOAc}$, dried and dissolved in $10 \mu \mathrm{l}$ of sterile double-distilled water. The dissolved DNA was $5^{\prime}$ end-labelled with $\left(\gamma-{ }^{32} \mathrm{P}\right] \mathrm{ATP}$ with T4 polynucleotide kinase (United States Biochemical, Cleve- 
land, OH, USA) according to the manufacturer's instructions.

\section{Hybridisation in dried agarose gels}

The general strategy for hybridisation in dried gels was adapted from Mather [44] and Lueders and Fewell [45]. Briefly, following electrophoretic separation of the digested DNA fragments, the agarose gel was placed on a piece of Whatman 3-mm paper, covered with plastic wrap and dried on a vacuum gel drier (Hoefer Scientific Instruments, San Francisco, CA, USA) for $30 \mathrm{~min}$ at room temperature and $30 \mathrm{~min}$ at $60^{\circ} \mathrm{C}$ followed by a 30 -min cooling period. Before hybridisation, the dried gel was placed in a dish of de-ionised water for a few minutes to remove the paper backing. The gel was then treated with $0.5 \mathrm{M} \mathrm{NaOH}, 0.15 \mathrm{M}$ $\mathrm{NaCl}$ for $45 \mathrm{~min}$ to denature the DNA, soaked in deionised water for $30 \mathrm{~min}$, then neutralised in $0.5 \mathrm{M}$ Tris-HCL, pH $7.5,0.15 \mathrm{M} \mathrm{NaCl}$ for $45 \mathrm{~min}$. The gel was washed for $30 \mathrm{~min}$ in de-ionised water then prehybridised for $3 \mathrm{~h}$ at $50^{\circ} \mathrm{C}$ with a solution containing $6 \times$ SSPE $\left(1 \times\right.$ SSPE is $20 \mathrm{mM} \mathrm{NaH} \mathrm{NO}_{4} \cdot \mathrm{H}_{2} \mathrm{O}$, $180 \mathrm{mM} \mathrm{NaCl}, 8 \mathrm{mM} \mathrm{NaOH}, 1 \mathrm{mM}$ EDTA, pH 7.0), $1 \times$ Denhardt's reagent, SDS $0.5 \% \mathrm{w} / \mathrm{v}$, denatured sonicated salmon sperm DNA, $100 \mu \mathrm{g} / \mathrm{ml}$ and sodium pyrophosphate (NaPPi) $0.05 \%$. Hybridisation was performed for $16 \mathrm{~h}$ at $50^{\circ} \mathrm{C}$ in the solution containing the radioactive rRNA probe. After hybridisation, gels were washed twice in $2 \times \operatorname{SSPE} \operatorname{SDS} 0.1 \% \mathrm{w} / \mathrm{v}$ at room temperature for $15 \mathrm{~min}$ each and once in $1 \times$ SSPE SDS $0.1 \% \mathrm{w} / \mathrm{v}$ at $60^{\circ} \mathrm{C}$ for $20 \mathrm{~min}$. Gels were autoradiographed with Kodak X-OMAT film at $-70^{\circ} \mathrm{C}$ with an intensifying screen.

\section{Statistical analysis}

The discrimination index (DI) of ribotyping and REA, i.e., the probability that two unrelated strains randomly selected from the test population would fall into different typing groups, was calculated by Simpson's index of diversity [46]. The percentage of similarity $(\% \mathrm{~S})$ between ribotypes was calculated as follows: $\% \mathrm{~S}=[($ number of matching bands $\times 2) /$ total number of bands] $\times 100$.

\section{Results}

\section{Serotyping}

All $81 P$. multocida isolates were confirmed as being capsular serogroup type A by the disk diffusion decapsulation test. Five serotypes were represented; these included one $\mathrm{A} 2,71 \mathrm{~A} 3$, three $\mathrm{A} 4$, one $\mathrm{A} 7$, four A10 and one untypable isolate. Serotype A3 represented $88 \%$ of total isolates, and $85 \%$ and $88 \%$ for beef and dairy cattle isolates, respectively. Serotype A10 isolates were all beef cattle isolates and represented $5 \%$ of total isolates and $12 \%$ of beef cattle isolates. In all, $4 \%$ of total isolates were serotype $\mathrm{A} 4$, which comprised one beef $(3 \%)$ and two dairy $(4 \%)$ cattle isolates. The single isolate serotypes A2 (dairy cattle), A7 (beef cattle) and the untypable isolate (dairy cattle) each comprised $1 \%$ of the total isolates.

\section{Ribotyping}

Preliminary experiments with different restriction endonucleases (REs) and RE combinations showed that Hae II was the most discriminating enzyme as judged by the number, range and variety of bands after hybridisation with the rRNA probe (data not shown). For that reason, Hae II was used in the ribotyping of the isolates under investigation. Ribotypes are defined as patterns of bands containing rRNA gene sequences and were assessed by including the preparations of DNA from isolates representative of known ribotypes in every Southern hybridisation experiment. Isolates were denoted as distinct when their hybridisation patterns differed by one or more bands. A total of six different ribotypes (designated R1-R6) was observed for the 81 isolates tested (Fig. 1) and these accounted for $57 \%$ (46), 21\% (17), 14\% (11), $6 \%$ (5), 1\% (1) and $1 \%(1)$ of

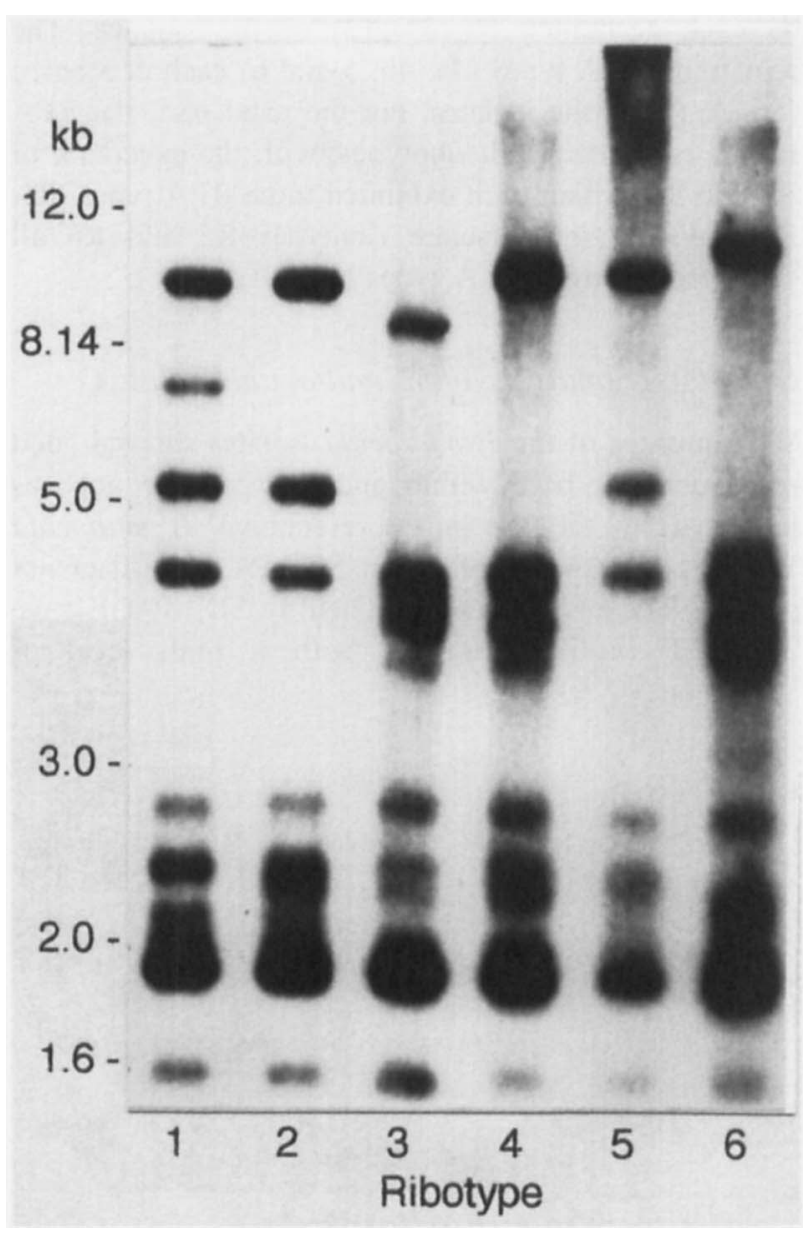

Fig. 1. Representative ribotypes of $P$. multocida bovine isolates. Lane 1, 9040970; 2, T94289; 3, 95120769; 4, $95110872 ; 5,96020298 ; 6$, T931317. Hybridisation was performed with ${ }^{32}$ P-labelled DNA probe of $16+23 \mathrm{~S}$ rRNA from $E$. coli. Note the similarity between R1, R2 and R5 and between R3, R4 and R6. Size markers in $(\mathrm{kb})$ are indicated. 
the total isolates, respectively. The numbers of bands in the six ribotypes varied from eight to nine with band sizes ranging from 1.6 to $>12 \mathrm{~kb}$. The six Hae II ribotypes revealed four monomorphic bands (1.6, 2.0, 2.6 and $4.3 \mathrm{~kb}$ ). The analysis of uncommon bands established 12 polymorphic Hae II restriction sites for the six ribotypes. R1 and R2 had two polymorphic bands at the anode and one at the cathode. R3 and R4 differed only in one polymorphic band at the cathode. R5 and R6 were single isolate ribotypes.

\section{Restriction enzyme analysis (REA)}

For REA, the large number of bands generated by digestion of genomic DNA with various restriction endonucleases hindered a detailed visual assessment of the method. Hae II was selected from the restriction endonucleases tested, because it displayed the most interpretable, consistent and discriminating restriction bands, the majority of which ranged between 1.6 and $12 \mathrm{~kb}$. The enzyme revealed 10 REA types (Fig. 2) among the $81 P$. multocida isolates. REA types 1,3 , and $2 \mathrm{c}$ accounted for $58 \%(47), 14 \%$ (11) and $12 \%$ (10) of the isolates, respectively. REA types $2 \mathrm{a}, 2 \mathrm{~b}$ and $4 \mathrm{a}$ each accounted for $4 \%$ (3) of the isolates. The remaining REA types (4a, 4b, 5 and 6) each accounted for $1 \%$ (1) of the isolates. For the most part, the REA results correlated with ribotypes, with the exception of R2 and R4, which each exhibited three REA types. R1, $\mathrm{R} 2$ and the single isolate ribotypes $\mathrm{R} 5$ and $\mathrm{R} 6$ all exhibited different REA types.

\section{SDS-PAGE analysis of P. multocida isolates}

WCP profiles of the $P$. multocida isolates showed good reproducibility both within and between the gels, as indicated by the use of representative $P$. multocida WCP as reference profiles on SDS-PA gels (data not shown). The 81 isolates examined by SDS-PAGE gave 36 WCP profiles (Fig. 3) with a high level of

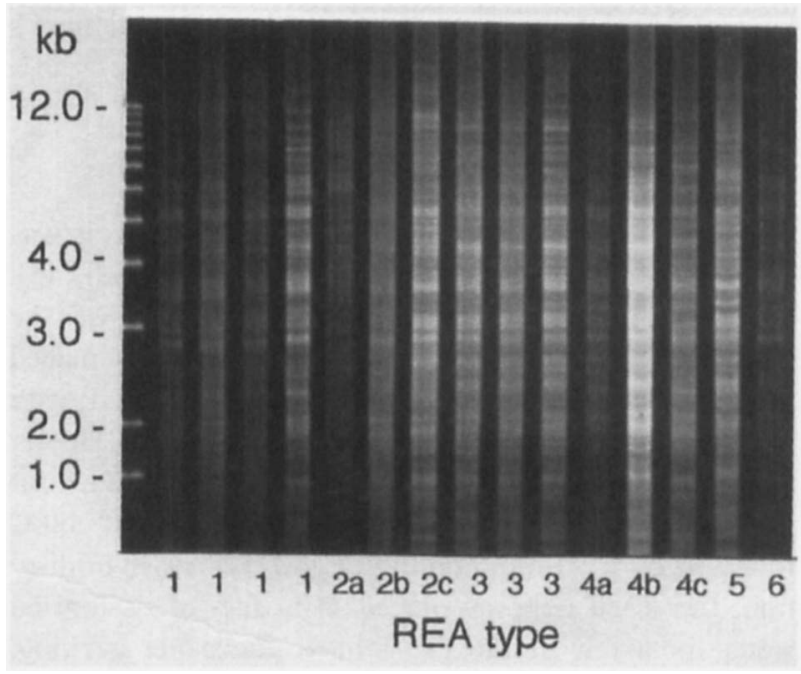

Fig. 2. REA profiles of Hae II-digested genomic DNA from $P$. multocida bovine isolates. Isolates in lanes 1 (REA type 1), 7 (REA type 2c), 8 (REA type 3), 13 (REA type 4c), 14 (REA type 5) and 15 (REA type 6) are representative of each ribotype and are as indicated in Fig. 1 for R1-R6. Size markers in (kb) are indicated.

polymorphisms within $\mathrm{R} 1, \mathrm{R} 2, \mathrm{R} 3$ and $\mathrm{R} 4$. WCP profile differences were based upon the presence, absence or intensity of protein bands. R1 alone had 17 different WCP profiles. However, the single isolate ribotypes R4 and R5 exhibited different WCP profiles and as such correlated with ribotype and REA results.

SDS-PAGE of OMP profiles revealed polymorphisms among the $12 P$. multocida isolates investigated (data not shown). The OMP profiles of isolates representative of the six ribotypes (Fig. 4) revealed six distinct OMP profiles.

\section{Analysis of isolates}

The study examined the $P$. multocida lung isolates for any association between ribotypes and (i) animal
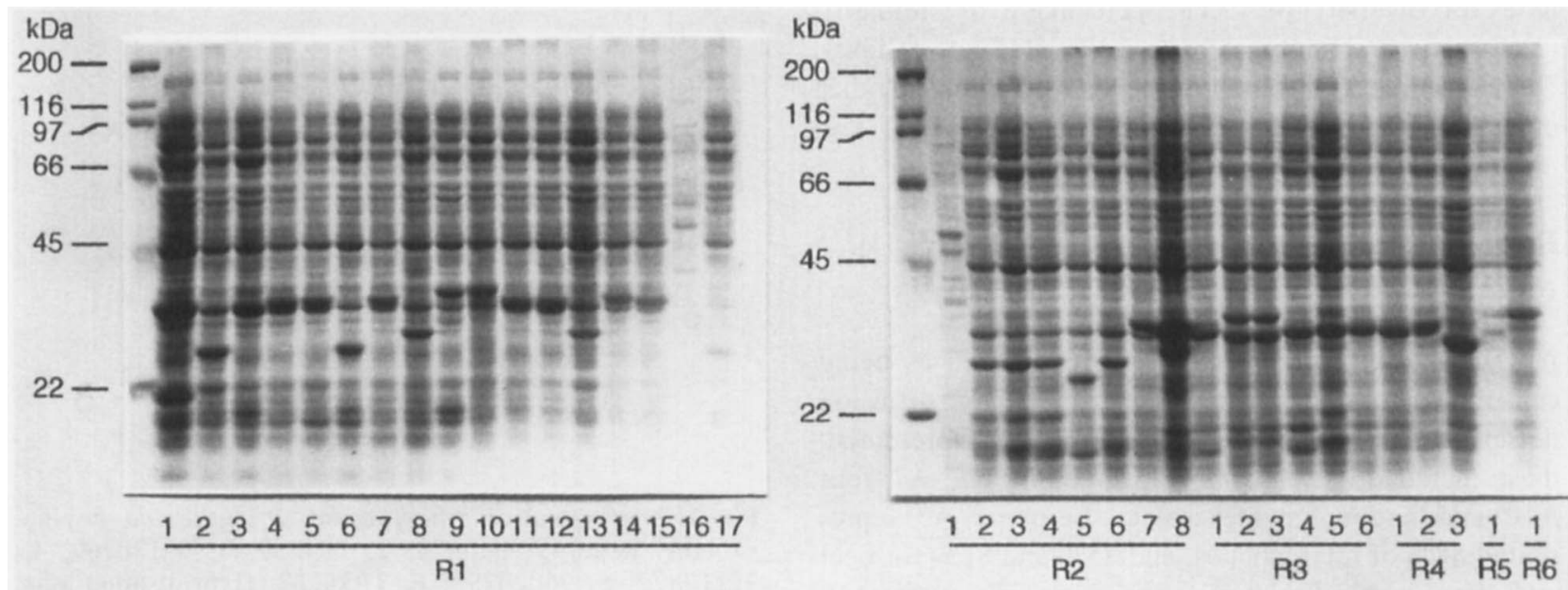

Fig. 3. Coomassie Blue-stained SDS $12.5 \%$ PA gel of WCP profiles of P. multocida bovine isolates representing the profiles reported in Table 3 and in the text. Note the high levels of polymorphisms within ribotype 1. Broad-range (BioRad) size markers (in $\mathrm{kDa}$ ) are indicated. 


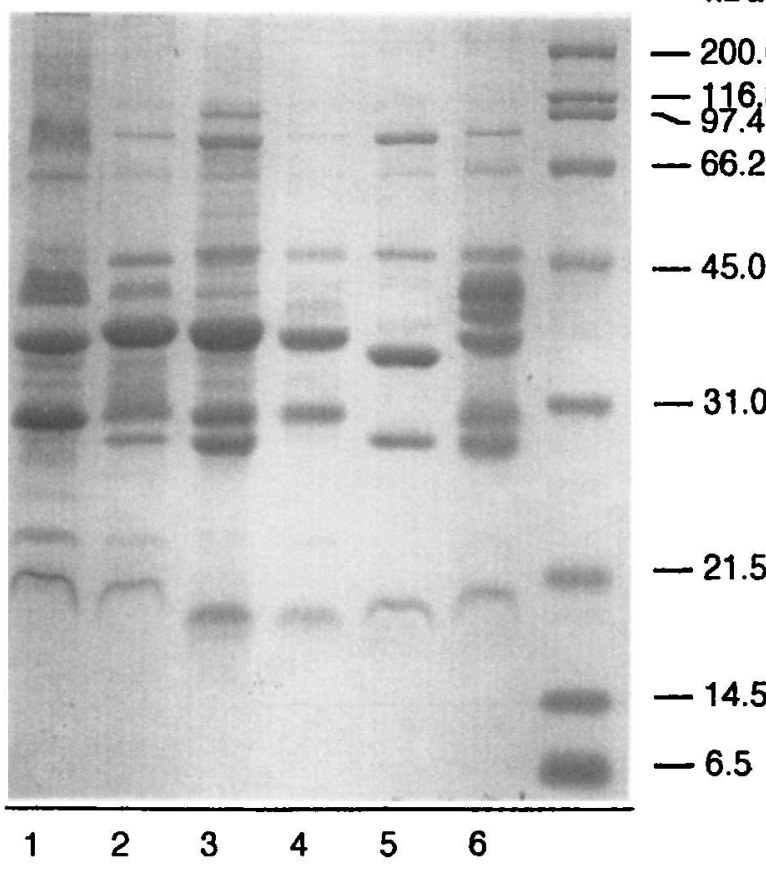

Fig. 4. Coomassie Blue-stained SDS $12.5 \%$ PA gel of OMPs of $P$. multocida bovine isolates representative of the six ribotypes. Isolates in lanes 1-6 are as indicated in Fig. 1 for R1-R6. Broad-range (BioRad) size markers (in $\mathrm{kDa}$ ) are indicated.

groups, (ii) geographical locations, (iii) sites of isolation and (iv) WCP pattern, serotype, REA type and ribotype. Of the isolates from Oklahoma, 55\% (28) (Table 2) were R1 pattern, and 57\% (16) of the isolates from California were R1 ribotype. Forty-six $(57 \%)$ of the $P$. multocida isolates from various geographical locations were $\mathrm{R} 1$. The association between ribotypes and animal groups were not as clear-cut. R1 represented $71 \%$ of the isolates from Holstein cattle; whereas R1 and R2 were dominant and equally represented among beef cattle (36\% and 39\% respectively). For both Holstein and beef cattle, lung isolates were predominantly $\mathrm{R} 1$, but for the nasal isolates, $\mathrm{R} 1$ predominated in Holstein and R2 in beef cattle. The single isolates of R5 (beef cattle nasal isolate) and R6 (Holstein lung isolate) originated from Oklahoma and California, respectively.

Isolates were grouped according to ribotype, WCP pattern, REA type and serotype with respect to whether they were nasal or lung, beef or Holstein cattle in origin (Table 3). For beef cattle lung isolates, R1 isolates contained five different WCP patterns among 10 isolates, one REA type and three different serotypes. Variations in WCP patterns and serotypes were also seen for R2 and R3. In contrast, Holstein cattle lung isolates of $\mathrm{R} 1$ contained eight different WCP patterns among 20 isolates, one REA type and a single serotype. WCP patterns varied for R2 and R3; however, REA types and serotypes were consistent for each of the ribotypes. Each beef cattle nasal isolate was of a single WCP pattern (except R2, which contained two different WCP patterns) and REA type for each of the five ribotypes represented. Furthermore, 17 of 18 isolates were A3. For Holstein nasal isolates, there was some variation among the R1 group as to WCP pattern and serotype; however, a single REA type and serotype was seen for both R1 and R4 and $R 4$, respectively.

\section{Statistical analysis}

Simpson's index of diversity [46] was used to evaluate the discrimination power of ribotyping and REA. The use of Hae II in both methods resulted in DI values of 0.60 and 0.63 for the six ribotypes and 10 REA types, respectively. This indicates that for both ribotyping and REA, when 2 isolates were randomly sampled from the tested population, they would fall into different types on at least $60 \%$ of the occasions. For ribotyping, the variation of the discrimination power with total lung isolates only (47) and isolates within diseased animal groups (32 and 15 for Holstein and beef cattle, respectively) was also evaluated. In all three cases the

Table 2. State of origin of $P$. multocida isolates with respect to ribotype

\begin{tabular}{|c|c|c|c|c|c|c|c|}
\hline \multirow[b]{2}{*}{ Origin } & \multirow{2}{*}{$\begin{array}{c}\text { Number of } \\
\text { cattle }\end{array}$} & \multicolumn{6}{|c|}{ Number of isolates of ribotype } \\
\hline & & $\mathrm{R} 1$ & $\mathrm{R} 2$ & R3 & $\mathrm{R} 4$ & R5 & R6 \\
\hline Beef cattle & 33 & & & & & & \\
\hline Lung & 15 & & & & & & \\
\hline Oklahoma & 13 & 7 & 3 & 3 & - & - & - \\
\hline Kansas & 1 & 1 & - & - & - & - & - \\
\hline Missouri & 1 & 1 & - & - & - & - & - \\
\hline Nose & 18 & & & & & & \\
\hline Oklahoma & 18 & 3 & 10 & 1 & 3 & 1 & - \\
\hline Holstein cattle & 48 & & & & & & \\
\hline Lung & 32 & & & & & & \\
\hline California & 28 & 16 & 3 & 7 & 1 & - & 1 \\
\hline Oklahoma & 4 & 4 & - & - & - & - & - \\
\hline Nose & 15 & & & & & & \\
\hline Oklahoma & 15 & 14 & - & - & 1 & - & - \\
\hline Testicle & 1 & & & & & & \\
\hline Oklahoma & 1 & - & 1 & - & - & - & - \\
\hline Total & - & 46 & 17 & 11 & 5 & 1 & 1 \\
\hline
\end{tabular}


Table 3. Grouping of $P$. multocida isolates by ribotypes, WCP patterns, REA types and serotypes

\begin{tabular}{|c|c|c|c|c|}
\hline Origin & Ribotype & $\begin{array}{c}\text { WCP } \\
\text { pattern }^{*}\end{array}$ & REA type & Serotype $\dagger$ \\
\hline \multicolumn{5}{|l|}{ Beef cattle } \\
\hline \multirow[t]{3}{*}{ Lung isolates } & $\mathrm{R} 1$ & $5 / 10$ & 1 & $\mathrm{~A} 10(2), \mathrm{A} 3(7), \mathrm{A} 4(1)$ \\
\hline & $\mathrm{R} 2$ & $3 / 3$ & $2 a$ & $\mathrm{~A} 3(3)$ \\
\hline & R3 & $3 / 3$ & 3 & $\mathrm{~A} 10(2), \mathrm{A} 3(1)$ \\
\hline \multirow[t]{5}{*}{ Nasal isolates } & $\mathrm{R} 1$ & $1 / 3$ & 1 & $\mathrm{~A} 3(3)$ \\
\hline & $\mathrm{R} 2$ & $2 / 10$ & $2 \mathrm{c}$ & $\mathrm{A} 3(9), \mathrm{A} 7(1)$ \\
\hline & $\mathrm{R} 3$ & $1 / 1$ & 3 & $\mathrm{~A} 3(1)$ \\
\hline & R4 & $1 / 3$ & $4 a$ & A3(3) \\
\hline & R5 & $1 / 1$ & 5 & A3(1) \\
\hline \multicolumn{5}{|l|}{ Holstein cattle } \\
\hline \multirow[t]{5}{*}{ Lung isolates } & R1 & $8 / 20$ & 1 & $\mathrm{~A} 3(20)$ \\
\hline & $\mathrm{R} 2$ & $3 / 3$ & $2 b$ & $\mathrm{~A} 3(3)$ \\
\hline & R3 & $2 / 7$ & 3 & $\mathrm{~A} 3(7)$ \\
\hline & R4 & $1 / 1$ & 4 & $\mathrm{~A} 4(1)$ \\
\hline & R6 & $1 / 1$ & 6 & UT(1) \\
\hline \multirow[t]{2}{*}{ Nasal isolates } & $\mathrm{R} 1$ & $3 / 14$ & 1 & $\mathrm{~A} 3(12), \mathrm{A} 4(1), \mathrm{A} 2(1)$ \\
\hline & R4 & $1 / 1$ & $4 c$ & $\mathrm{~A} 3(1)$ \\
\hline
\end{tabular}

* Expressed as number of different WCP patterns/number of isolates.

$\dagger$ Numbers in parentheses are the numbers of isolates of the serotype.

isolates were discriminated with a DI of 0.60 , similar to that reported above for the whole test population. The percentage similarity between ribotypes is shown in Table 4. The results suggest that $\mathrm{R} 1, \mathrm{R} 2$ and $\mathrm{R} 5$ ( $71-88 \%$ similarity) are related, as are R3, R4 and R6 (89\% similarity).

The discriminatory power of WCP patterns expressed as the number of different WCP profiles/number of iso-lates revealed a high frequency of polymorphism within R1, R2 and R3 for both Holstein and beef cattle lung isolates as compared with nasal isolates (Table 3). Only R1 Holstein and R2 beef cattle nasal isolates exhibited some WCP polymorphisms.

\section{Discussion}

Radiolabelled $E$. coli rRNA was used successfully as a broad-spectrum probe to characterise 81 bovine $P$. multocida isolates from healthy and diseased dairy and beef cattle originating from different geographical locations. The isolates were also subtyped by serotyping, REA of whole genomic DNA, and WCP and OMP profiles. Characterisation of the isolates by serotyping turned out to be of limited value as reported previously $[35,47] ;>88 \%$ of the isolates were of the same serotype, A3, consistent with previous reports [6-9].

The 81 P. multocida isolates were discriminated into

Table 4. Percentage similarity between ribotypes

\begin{tabular}{lcccccc}
\hline Ribotype & R1 & R2 & R3 & R4 & R5 & R6 \\
\hline R1 & - & 82 & 56 & 56 & 71 & 42 \\
R2 & & - & 71 & 71 & 88 & 71 \\
R3 & & & - & 89 & 71 & 89 \\
R4 & & & & - & 82 & 89 \\
R5 & & & & & - & 71 \\
\hline
\end{tabular}

six ribotypes with Hae II restriction endonuclease. Towsend et al. [38] reported seven distinct ribotypes for both EcoRI and PstI-digested DNA among 19 haemorrhagic septicaemia (HS)-associated and nonassociated $P$. multocida isolates from Asia, Africa and North America. There was a high degree of homogeneity among the $P$. multocida isolates within geographical locations with the exception of the African P. multocida isolates, which exhibited similarities with various unrelated isolates. In this study, the Hae II enzyme alone produced easily interpretable rRNA banding patterns with a high discriminatory power of 0.60 . This DI was identical to those calculated for $P$. multocida lung isolates and for isolates within each diseased animal group. R1 alone and R2, R3 and R4 together made up $57 \%$ and $41 \%$ of the isolates, respectively. The remaining $2 \%$ included single isolate ribotypes 5 and 6 .

Differences between R1, R2 and R5 and between R3, R4 and R6 were small when based upon the percentage similarity and the number of polymorphic bands. These Hae II ribotype differences clearly grouped the bovine $P$. multocida isolates into two major clusters. As indicated by Townsend et al. [38], DNA macrosection differences of up to three fragments are probably representative of genotypic variants of the same isolate. Therefore, the above ribotype differences were probably caused by small genomic re-arrangements, such as insertion or deletion around the Hae II restriction site, primarily between the rRNA transcriptional units.

The large number of bands resulting from REA is an obstacle when comparing large numbers of isolates. Nevertheless, REA of genomic DNA, performed by digestion with Hae II, revealed 10 REA types with a DI of 0.60 . In general, REA results correlated with 
ribotypes. In a few cases where ribotyping was found to be less discriminatory than the REA of genomic DNA, it is possible that the maximal level of sensitivity of the ribotyping may not have been reached by the use of a single Hae II restriction endonuclease. Previous studies indicated that increasing the number of enzymes used in ribotyping is usually followed by an increase in discriminatory power $[30,47]$.

To our knowledge, no discriminating data are available for ribotyping of bovine $P$. multocida serogroup A isolates from the respiratory tract on the basis of animal group, site of isolation or geographical location. The data from the present study convincingly showed no association between geographical locations and ribotypes as indicated by the predominance of $\mathrm{R} 1$ in all geographical locations. However, R1 seemed to be most representative of isolates from Holstein calves (74\%) and lung $(63 \%)$. The preponderance of $\mathrm{R} 1$ in particular, and to some extent R2 and R3, in all geographical locations suggest a spread of infection resulting from the same source or a single clone. This may have occurred over time as infected cattle were moved from one area to another within and between states. In contrast, Townsend et al. [38] reported some correlation between ribotype and geographical origin of HS-causing P. multocida isolates. However, the geographical locations varied greatly in their study and included Asia, Africa and North America. Chlaslus-Dancla et al. [31], in their ribotyping study of Pasteurella species isolated from animals, reported limited polymorphism in bovine $P$. haemolytica strains from independent breeding herds and high diversity in P. multocida strains from rabbit farms. They hypothesised that high selective pressure by antibiotics may have introduced an evolutionary constraint on bovine $P$. haemolytica with drastic consequences on their genetic polymorphism. There was no indication of such high selective pressure by antibiotics on the bovine $P$. multocida isolates in this study. A more complete ribotype study with isolates from outbreaks of pneumonia within dairy herds would be necessary to determine consistency of various ribotypes in those situations.

The isolates were also subtyped by WCP and OMP. Unlike serotyping and REA, WCP exhibited high frequency of polymorphisms within and between ribotypes. Most polymorphisms seen in WCP were in lung isolates. Although a definitive correlation between ribotypes and WCP profiles was not observed, the single isolate ribotypes exhibited different WCP profiles. OMP subtyping was able to discriminate between isolates representative of the six ribotypes.

In conclusion, ribotyping was clearly discriminating and six ribotypes were observed for the $81 P$. multocida serogroup A bovine isolates. The six Hae II ribotypes may have originated from two $P$. multocida genetic variants through small genomic re-arrangements such as deletion or insertion around the Hae II restriction site. REA, OMP and WCP analysis, with all their reported limitations, can be useful complements to ribotyping in epidemiological and taxonomic studies of $P$. multocida isolates from cattle.

This study was supported in part by Oklahoma Agricultural Experiment Station projects 01438 and 02255 .

\section{References}

1. Frank GH. Pasteurellosis of cattle. In: Adlam C, Rutter JM (eds) Pasteurella and pasteurellosis. London, Academic Press. 1989.

2. Gonzalez CT, Maheswaran SK. The role of induced virulence factors produced by Pasteurella haemolytica in the pathogenesis of bovine pneumonic pasteurellosis: review and hypothesis. Br Vet J 1993; 149: 183-193.

3. Heddleston KL, Gallagher JE, Rebers PA. Fowl cholera: gel diffusion precipitin test for serotyping Pasteurella multocida from avian species. Avian Dis 1972; 16: 925-936.

4. Dungworth DC. The respiratory system. In: Jubb KVF, Kennedy PC, Palmer N (eds) Pathology of domestic animals, vol. 2. Orlando, Academic Press. 1985: 448-489.

5. Rimler RB, Rhoades KR. Pasteurella multocida In: Adlam C, Rutter JM (eds) Pasteurella and pasteurellosis. London, Academic Press. 1989: 37.

6. Bryson DG, McFerran JB, Ball HJ, Neill SD. Observation on outbreaks of respiratory disease in housed calves. (1) Epidemiological, clinical, and microbiological findings. Vet Rec 1978; 103: 485-489.

7. Dungworth DC. The respiratory system. In: Jubb KVF, Kennedy PC, Palmer N (eds) Pathology of domestic animals, vol 2. Orlando, Academic Press. 1993: 632-639.

8. Haritani MS, Nakazawa M, Hashimoto K, Narita M, Tagawa Y, Nakagawa $M$. Immunoperoxidase evaluation of the relationship between necrotic lesions and causative bacteria in lungs of calves with naturally acquired pneumonia. Am J Vet Res 1990; 51: $1975-1979$.

9. Welsh RD. Bacterial and Mycoplasma species isolated from pneumonic bovine lungs. Agr-Pract 1995; 14 12-16.

10. Aber RC, Mackel DC. Epidemiologic typing of nosocomial microorganisms. Am J Med 1981; 70: 899-905.

11. Akhtar N, Eley A. Restriction endonuclease analysis and ribotyping differentiate genital and nongenital strains of Bacteroides ureolyticus. J Clin Microbiol 1992; 30; 24082414.

12. Duclos P, Freney J, Caillet J, Alexander H, Garonnat D. Carbon source assimilation and fermentation tests: study of 77 animal Pasteurella strains by a microtechnique Comp Immunol Microbiol Infect Dis 1986; 9: 47-51.

13. Kirchner C, Eisenstark A. Lysogeny in Pasteurella multocida. Am $J$ Vet Res 1956; 17: 547-548.

14. Lester A, Gerner-Smidt P, Gahrn-Hansen B, Sogaard P, Schmidt J, Frederiksen W. Phenotypical characters and ribotyping of Pasteurella aerogenes from different sources. Int $\mathrm{J} \mathrm{Med}$ Microbiol Virol Parasitol Infect Dis 1993; 279: 75-82.

15. Mohan K, Sadza M, Madsen M, Hill FWG, Pawandiwa A. Phenotypic characterization of Zimbabwean isolates of Pasteurella multocida. Vet Microbiol 1994; 38: 351-357.

16. Murphy GL, Robinson LC, Burrows GE. Restriction endonuclease analysis and ribotyping differentiate Pasteurella haemolytica serotype A1 isolates from cattle within a feedlot. J Clin Microbiol 1993; 31: 2303-2308.

17. Nagai $S$, Someno $S$, Yagihashi $T$. Differentiation of toxigenic from nontoxigenic isolates of Pasteurella multocida by PCR. J Clin Microbiol 1994; 32: 1004-1010.

18. Riegel P, Freitas FIS, Prévost G et al. Comparison of traditional and molecular methods for typing nontoxigenic strains of Corynebacterium diphtheriae. Eur J Clin Microbiol Infect Dis 1997; 16: 610-614.

19. Rimler RB. Presumptive identification of Pasteurella multocida serogroups $\mathrm{A}, \mathrm{D}$ and $\mathrm{F}$ by capsule depolymerisation with mucopolysaccharidases. Vet Rec 1994; 134: 191-192. 
20. Carpenter TE, Snipes KP, Kasten RW, Hird DW, Hirsh DC Molecular epidemiology of Pasteurella multocida in turkeys. Am $J$ Vet Res 1991; 52: 1345-1349.

21. Jackman PJH. Microbial systematics based on electrophoretic whole-cell protein patterns. In: Colwell RR, Grigorova R (eds) Methods in microbiology, vol 19. London, Academic Press. 1987: 209-225.

22. Schimmel D, Sachse K. Classification of Pasteurella field strains isolated from farms in Germany using traditional methods and DNA-DNA hybridization. Int $J$ Med Microbiol Virol Parasitol Infect Dis 1993; 279: 125-130.

23. Snipes KP, Hirsh DC, Kasten RW, Carpenter TE, Hird DW, McCapes RH. Homogeneity of characteristics of Pasteurella multocida isolates from turkeys and wildlife in California 1985-1988. Avian Dis 1990; 34: 315-320.

24. Taylor AJ, Costas M, Owen RJ. Numerical analysis of electrophoretic protein patterns of Bacteroides ureolyticus clinical isolates. $J$ Clin Microbiol 1987; 25: 660-666.

25. Taylor AJ, Dawson CA, Owen RJ. The identification of Bacteroides ureolyticus from patients with non-gonococcal urethritis by conventional biochemical tests and by DNA and protein analyses. J Med Microbiol 1986; 21: 109-116.

26. Collins DM, Gabric DM, De Lisle GW. Identification of two groups of Mycobacterium paratuberculosis strains by restriction endonuclease analysis and DNA hybridization. J Clin Microbiol 1990; 28: $1591-1596$.

27. Owen RJ. Chromosomal DNA fingerprinting - a new method of species and strain identification applicable to microbial pathogens $J$ Med Microbiol 1989; 30: 89-99.

28. Snipes KP, Hirsh DC, Kasten RW, Carpenter TE, Hird DW, McCapes RH. Differentiation of field isolates of Pasteurella multocida serotype 3, 4 from live vaccine strain by genotypic characterization. Avian Dis 1990; 34: 419-424.

29. Altwegg M, Hickman-Brenner FW, Farmer JJ. Ribosomal RNA gene restriction patterns provide increased sensitivity for typing Salmonella typhi strains. J Infect Dis 1989: 160: 145-149.

30. Bingen EH, Denamur E, Elion J. Use of ribotyping in epidemiological surveillance of nosocomial outbreaks. Clin Microbiol Rev 1994: 7: 311-327.

31. Chaslus-Dancla E, Lesage-Descauses MC, Leroy-Sétrin S Martel JL, Coudert $P$, Lafont JP. Validation of random amplified polymorphic DNA assays by ribotyping as tools for epidemiological surveys of Pasteurella from animals. Vet Micobiol 1996; 52: 91-102.

32. Grimont F, Grimont PAD. Ribosomal ribonucleic acid gene restriction patterns as potential taxonomic tools. Ann Inst Pasteur Microbiol 1986; 137B: 165-175.

33. Zhao G, Pijoan C, Murtaugh MP, Molitor TW. Use of restriction endonuclease analysis and ribotyping to study epidemiology of Pasteurella multocida in closed swine herds. Infect Immun 1992; 60: 1401-1405.
34. Snipes KP, Hirsh DC, Kasten RW et al. Use of an rRNA probe and restriction endonuclease analysis to fingerprint Pasteurella multocida isolated from turkeys and wildlife. J Clin Microbiol 1989; 27: 1847-1853.

35. Stull TL, LiPuma JJ, Edlind TD. A broad-spectrum probe for molecular epidemiology of bacteria: ribosomal RNA. $J$ Infect Dis 1988; 157: 280-286.

36. Sarafian SK, Woods TC, Knapp JS, Swaminathan B, Morse SA. Molecular characterization of Haemophilus ducreyi by ribosomal DNA fingerprinting. J Clin Microbiol 1991; 29 . 1949-1954.

37. Wiedmann M, Bruce JL, Keating C, Johnson AE, McDonough PL, Batt CA. Ribotypes and virulence gene polymorphisms suggest three distinct Listeria monocytogenes lineages with differences in pathogenic potential. Infect Immun 1997; 65: 2707-2716.

38. Townsend KM, Dawkins HJS, Papadimitriou JM. Analysis of haemorrhagic septicaemia-causing isolates of Pasteurella multocida by ribotyping and field alternation gel electrophoresis (FAGE). Vet Microbiol 1997; 57: 383-395.

39. Wilson MA, Rimler RB, Hoffman LJ. Comparison of DNA fingerprints and somatic serotypes of serogroup B and $\mathrm{E}$ Pasteurella multocida isolates. J Clin Microbiol 1993; 30: 1518-1534.

40. Simons KR, Morton RJ, Fulton RW, Confer AW. Comparison of antibody responses in cattle to outer membrane proteins from Pasteurella haemolytica serotype 1 and from eight untypeable strains. Am J Vet Res 1992; 53: 971-975.

41. Knights JM, Adlam C, Owen P. Characterization of envelope proteins from Pasteurella haemolytica and Pasteurella multocida. J Gen Microbiol 1990; 136: 495-505.

42. Dabo SM, Confer AW, Murphy GL. Outer membrane proteins of bovine Pasteurella multocida serogroup A isolates. Vet Microbiol 1997; 54: 167-183.

43. Sambrook J, Fritsch EF, Maniatis T. Molecular cloning: a laboratory manual, 2nd edn. Cold Spring Harbor, NY, Cold Spring Harbor Laboratory Press. 1989.

44. Mather MW. Base composition-independent hybridization in dried agarose gels: screening and recovery for cloning of genomic DNA fragments. Biotechniques 1988; 6: 444-447.

45. Lueders KK, Fewell JW. Hybridization of DNA in dried gels provides increased sensitivity compared with hybridization to blots. Biotechniques 1994; 16: 66-67.

46. Hunter PR, Gaston MA. Numerical index of the discriminatory ability of typing systems: an application of Simpson's index of diversity. J Clin Microbiol 1988; 26: 2465-2466.

47. Blumberg HM, Stephens DS, Lieitra C et al. Molecular epidemiology of group B streptococcal infections: use of restriction endonuclease analysis of chromosomal DNA and DNA restriction fragment length polymorphisms of ribosomal RNA genes (ribotyping). J Infect Dis 1992; 166: $574-579$. 